\title{
Simulation of wheat yield by nitrogen and nonlinearity of environmental conditions
}

\author{
Ana P. B. Trautmann ${ }^{1}$, José A. G. da Silva ${ }^{2}$, Manuel O. Binelo ${ }^{1}$, Antonio C. Valdiero ${ }^{3}$, Luana Henrichsen ${ }^{1} \&$ \\ Natiane C. F. Basso ${ }^{2}$ \\ ${ }^{1}$ Universidade Regional do Noroeste do Estado do Rio Grande do Sul/Departamento de Ciências Exatas e Engenharias. Ijuí, RS, Brasil. E-mail: \\ anabrezolin@hotmail.com (Corresponding author) - ORCID: 0000-0003-2194-6738; manuel.binelo@gmail.com - ORCID: 0000-0001-7639-7663; \\ luanabehnenh@gmail.com - ORCID: 0000-0003-0522-5666 \\ ${ }^{2}$ Universidade Regional do Noroeste do Estado do Rio Grande do Sul/Departamento de Estudos Agrários. Ijuí, RS, Brasil. E-mail: jagsfaem@yahoo.com.br - \\ ORCID: 0000-0002-9335-2421; natianeferrari@gmail.com - ORCID: 0000-0002-6538-7299 \\ ${ }^{3}$ Universidade Federal de Goiás/Faculdade de Engenharia. Catalão, GO, Brasil. E-mail: antoniocvaldiero@gmail.com - ORCID: 0000-0001-7447-2076
}

\begin{abstract}
Fuzzy logic can simulate wheat productivity by assisting crop predictability. The objective of the study is the use of fuzzy logic to simulate wheat yield in the conditions of nitrogen use, together with the effects of air temperature and rainfall, in the main cereal succession systems in Southern Brazil. The study was conducted in the years 2014, 2015 and 2016, in Augusto Pestana, RS, Brazil. The experimental design was a randomized block design with four repetitions in a $4 \times 3$ factorial scheme for $\mathrm{N}$-fertilizer doses $(0,30,60$, $120 \mathrm{~kg} \mathrm{ha}^{-1}$ ) and nutrient supply forms [100\% in phenological stage $\mathrm{V}_{3}$ (third expanded leaf); (70\%/30\%) in the phenological stage $\mathrm{V}_{3} / \mathrm{V}_{6}$ (third and sixth expanded leaf) and; fractionated $(70 \% / 30 \%)$ at the phenological stage $\mathrm{V}_{3} / \mathrm{E}$ (third expanded leaf and beginning of grain filling)], respectively, in the soybean/wheat and corn/ wheat systems. The pertinence functions and the linguistic values established for the input and output variables are adequate for the use of fuzzy logic. Fuzzy logic simulates wheat grain yield efficiently in the conditions of nitrogen use with air temperature and rainfall in crop systems.
\end{abstract}

Key words: Triticum aestivum, temperature, precipitation, fuzzy logic, modeling

\section{Simulação da produtividade do trigo pelo nitrogênio e não linearidade das condições ambientais}

RESUMO: A lógica fuzzy pode simular a produtividade do trigo auxiliando na previsibilidade de safras. Objetivou-se no estudo o uso de lógica fuzzy para simulação da produtividade do trigo nas condições de uso do nitrogênio junto aos efeitos de temperatura do ar e precipitação pluviométrica, nos principais sistemas de sucessão do cereal no sul do Brasil. O estudo foi conduzido nos anos de 2014, 2015 e 2016, em Augusto Pestana, RS, Brasil. O delineamento experimental foi o de blocos casualizados com quatro repetições em fatorial $4 \times 3$, para doses de $\mathrm{N}$-fertilizante $\left(0,30,60,120 \mathrm{~kg} \mathrm{ha}^{-1}\right)$ e formas de fornecimento do nutriente [condição única (100\%) no estádio fenológico $\mathrm{V}_{3}$ (terceira folha expandida); fracionada (70\%/30\%) no estádio fenológico $\mathrm{V}_{3} / \mathrm{V}_{6}$ (terceira e sexta folha expandida) e; fracionada (70\%/30\%) no estádio fenológico $\mathrm{V}_{3} / \mathrm{E}$ (terceira folha expandida e início do enchimento de grãos)], respectivamente, no sistema soja/trigo e milho/trigo. As funções de pertinências e os valores linguísticos estabelecidos para as variáveis de entrada e de saída se mostram adequados para o uso da lógica fuzzy. A lógica fuzzy simula com eficiência a produtividade de grãos de trigo nas condições de uso do nitrogênio com temperatura do ar e precipitação pluviométrica nos sistemas de cultivo.

Palavras-chave: Triticum aestivum, temperatura, precipitação, lógica fuzzy, modelagem 


\section{INTRODUCTION}

The prior and precise knowledge of agricultural harvests is a strategic issue in world agriculture (Gomes et al., 2014; Marolli et al., 2018). Predicting with efficiency has been a complex activity, due to the different managements, types of soils and climates (Crusiol et al., 2016; Marolli et al., 2017). Mathematical models that seek efficient simulations, describing complex interactions with the nonlinear effects of agroecosystems are nincreasingly being sought (Rosa et al., 2015; Mantai et al., 2017). In this perspective, fuzzy models are techniques that allow the description of complex systems, produced from rules elaborated by specialists, providing their experience to the elaboration of an inference system of the type "If <condition> Then < result>" (Barros \& Bassanezi, 2010; Silva et al., 2014).

Wheat is a cereal of great importance in the global economy (Santos et al., 2016; Goergen et al., 2017), but it is strongly dependent on nitrogen in the expression of productivity (Camponogara et al., 2016; Costa et al., 2018). The efficiency of nitrogen to production elaboration is dependent on the nonlinearity of environmental conditions, mainly rainfall and air temperature (Acosta et al., 2014; Mantai et al., 2016). Under real conditions, the proper timing of nitrogen supply does not always coincide with adjusted conditions of soil moisture and air temperature, changing the efficiency of nutrient utilization and, consequently, the expected productivity (Acosta et al., 2014; Arenhardt et al., 2015).

The use of fuzzy logic can represent an efficient tool for the simulation of productivity, involving the nonlinear relationships of environmental conditions in nitrogen supply in real agricultural systems. Therefore, the objective of this study is to use fuzzy logic to simulate wheat grain yield under nitrogen use conditions along with the effects of air temperature and rainfall, considering the main systems of cereal succession in southern Brazil.

\section{Materials ANd Methods}

The study was carried out in 2014, 2015 and 2016, in the municipality of Augusto Pestana, RS, Brazil ( $28^{\circ} 26^{\prime} 30^{\prime \prime} \mathrm{S}, 54^{\circ}$ 0 ' $58^{\prime \prime} \mathrm{W}$ and altitude of $400 \mathrm{~m}$ ). The soil of the experimental area is classified as an Oxisol and the climate of the region, according to the Köeppen classification, is of the CFA type, having hot summer without dry season. Ten days before sowing, soil analysis was performed and the following chemical characteristics were identified in the averages of the years (Tedesco et al.,1995): i) soybean/wheat system $(\mathrm{pH}=6,1, \mathrm{P}=$ $49,1 \mathrm{mg} \mathrm{dm}^{-3}, \mathrm{~K}=424 \mathrm{mg} \mathrm{dm}^{-3}, \mathrm{MO}=3,0 \%, \mathrm{Al}=0 \mathrm{cmol}_{\mathrm{c}} \mathrm{dm}^{-3}$, $\mathrm{Ca}=6,3 \mathrm{cmol}_{\mathrm{c}} \mathrm{dm}^{-3}$ and $\mathrm{Mg}=2,5 \mathrm{cmol}_{\mathrm{c}} \mathrm{dm}^{-3}$ ) and; ii) corn/ wheat system $\left(\mathrm{pH}=6,5, \mathrm{P}=23,6 \mathrm{mg} \mathrm{dm}^{-3}, \mathrm{~K}=295 \mathrm{mg} \mathrm{dm}^{-3}\right.$, $\mathrm{MO}=2,9 \%, \mathrm{Al}=0 \mathrm{cmol}_{\mathrm{c}} \mathrm{dm}^{-3}, \mathrm{Ca}=6,8 \mathrm{cmol}_{\mathrm{c}} \mathrm{dm}^{-3}$ and $\mathrm{Mg}=$ $3,1 \mathrm{cmol} \mathrm{dm}^{-3}$ ). Independent of agricultural year, sowing was performed based on the technical indications of the species, with a seeder-fertilizer for composition of plots with 5 rows of 5 $\mathrm{m}$ long and spaced $0.20 \mathrm{~m}$, forming an experimental unit of $5 \mathrm{~m}^{2}$. During sowing, 30 and $20 \mathrm{~kg} \mathrm{ha}^{-1}$ of $\mathrm{P}_{2} \mathrm{O}_{5}$ and $\mathrm{K}_{2} \mathrm{O}$ were applied, respectively, based on soil $\mathrm{P}$ and $\mathrm{K}$ concentrations for grain yield expectation of $3 \mathrm{tha}^{-1}$ and $\mathrm{N}$ in the base with 10 $\mathrm{kg} \mathrm{ha}^{-1}$, with nitrogen available in the form of urea. The seeds were subjected to germination test and vigor in a laboratory, in order to correct the desired density of 400 viable seeds $\mathrm{m}^{-2}$. During the execution of the study, applications of Tebuconazole fungicide were performed at the dose of $0.75 \mathrm{~L} \mathrm{ha}^{-1}$. Weed control was performed with a metsulfuron-methyl herbicide at a dose of $4 \mathrm{~g} \mathrm{ha}^{-1}$. In the study, the wheat cultivar used was BRS Guamirim of low-size, early cycle, resistant to lodging, of commercial class type "bread" of high productive potential. This cultivar represents the standard biotype commonly desired by the growers in Southern Brazil.

In each cultivation system (soybean/wheat, corn/wheat system), the experimental design was a randomized block design with four repetitions in a $4 \times 3$ factorial scheme for $\mathrm{N}$-fertilizer doses $\left(0,30,60,120 \mathrm{~kg} \mathrm{ha}^{-1}\right)$ and forms of nutrient supply [single condition $(100 \%)$ at phenological stage $\mathrm{V}_{3}$ (expanded third leaf); fractionated (70\%/30\%) at the phenological stage $\mathrm{V}_{3} / \mathrm{V}_{6}$ (third and sixth expanded leaf) and fractionated $(70 \% / 30 \%)$ in the phenological stage $\mathrm{V}_{3} / \mathrm{E}$ (third expanded leaf and initiation of grain filling)], respectively, totaling 96 experimental units. In all years of cultivation, $\mathrm{N}$-fertilizer application at $\mathrm{V}_{3}, \mathrm{~V}_{6}$ and $\mathrm{E}$ stages were at 30,60 and 90 days after wheat emergence, respectively. The experiments were harvested to estimate grain yield manually by cutting the three central lines of each plot, near the harvest point (135 days), with grain moisture around 15\%. After harvest, the grains were tracked with a stationary harvester and sent to the laboratory to correct grain moisture to $13 \%$, after weighing and yield estimation.

The values of productivity with the information of air temperature and rainfall were used to classify the agricultural years as unfavorable, reasonable and favorable to the cultivation of wheat. The maximum and minimum temperature information for the calculation of the thermal sum and rainfall were obtained by the Automatic Total Station installed at 500 $\mathrm{m}$ from the experiment. Thermal sum (TS) was obtained from the emergence of plants by the model:

$$
\mathrm{TS}=\sum_{\mathrm{i}=1}^{\mathrm{n}}\left(\frac{\mathrm{T}_{\max }+\mathrm{T}_{\min }}{2}\right)-\mathrm{Tb}
$$

where:

$\mathrm{T}_{\max }$ - maximum temperature;

$\mathrm{T}_{\min }$ - minimum temperature;

n - number of days from emergence period to harvest; and,

$\mathrm{Tb}$ - base temperature. The wheat base temperature used in the study was $4{ }^{\circ} \mathrm{C}$ (Pedro Júnior et al., 2004).

In fuzzy modeling, the input variables (independent) were nitrogen doses $\left(\mathrm{N}, \mathrm{kg} \mathrm{ha}^{-1}\right)$, thermal sum (TS, degrees $\left.\mathrm{d}^{-1}\right)$ and rainfall $(\mathrm{PP}, \mathrm{mm})$, with variable output (dependent) grain yield (PG, $\mathrm{kg} \mathrm{ha}^{-1}$ ). The information obtained was organized and classified in linguistic terms for the composition of the rules base by the help of a specialist, considering the set of results from three agricultural seasons. For the thermal sum (degrees $\mathrm{d}^{-1}$ ), the interval domain $[1370,1803]$ was considered, representing the ranges: $<1575$ [Low (B)] and > $1575[$ High 
(A)]. In the supply of nitrogen $\left(\mathrm{kg} \mathrm{ha}^{-1}\right)$, the interval domain $[0,120]$ was considered, representing the ranges: $<30$ [low dose (B)]; 30-90 [intermediate dose (I)] and $>90$ [high dose (A)]. For rainfall $(\mathrm{mm})$, the interval domain $[777,1009]$ was defined, representing the ranges: $<893$ [Low (B)] and $>893$ [High (A)]. In the output variable [grain yield $\left(\mathrm{kg} \mathrm{ha}^{-1}\right)$ ], the image intervals represent the maximum and minimum values of experimentally collected data, considering the averages of the different years of evaluation. Six simulators were built for the conditions of nitrogen use in each succession system. The grain yield variable was divided into four equidistant intervals (Table 1): very low (MB), low (B), mean (M) and high (A). Although the construction of the rule base is the same in both systems, the lower and upper limits of grain yield were changed according to expected productivity in each system of high succession (soybean/wheat) and reduced (corn/wheat) $\mathrm{N}$-residual release.

In the elaboration of the model, the Fuzzy Rule Based System (SBRF) was used, implemented by the Fuzzy Logic Toolbox of the Matlab software. In the prediction applications, the Mamdani fuzzy model was used, which includes interface modules in the transformation of input variables into diffuse sets and, later outputs in proportional numerical quantities (Cecconello et al., 2010). The fuzzification process occurred by 4 successive modules. In module 1 (fuzzification), the input variable information was mathematically modeled using fuzzy sets. From the specialist, each input variable was assigned linguistic terms representing the states of this variable and, each linguistic term is associated with a fuzzy set by a function of pertinence. In Module 2 (rule base), the variables were adjusted in their linguistic classifications, where each rule base satisfied the following structure:

\section{If $A$ is in $A_{i}$ then $B$ is in $B_{i}$}

$A_{i}$ and $B_{i}$ being the fuzzy sets. The expression $A$ is in $A_{i}$ means that $\mu_{\mathrm{A}_{\mathrm{i}}}(\mathrm{a}) \in[0,1]$. Both the $\mathrm{A}_{\mathrm{i}}$ and $\mathrm{B}_{\mathrm{i}}$ sets are the Cartesian product of fuzzy sets, that is, $A_{1}=A_{i 1} \times A_{i 2} \times \ldots \times A_{i m}$ and $B_{i}=B_{i 1} \times B_{i 2} \times \ldots \times B_{i n}$. In this case, each fuzzy set $A_{i j}$ and $B_{i k}$ represented a linguistic term for the J-th input variable and $\mathrm{k}$-th output variable, and expression $\mathrm{A}$ is in $\mathrm{A}_{\mathrm{i}}$ which means:

$$
\mu_{\mathrm{A}_{\mathrm{i}}}(\mathrm{a})=\min \left\{\mu_{\mathrm{A}_{\mathrm{i} 1(\mathrm{a})}}, \mu_{\mathrm{A}_{\mathrm{i} 2(\mathrm{a})}}, \ldots, \mu_{\mathrm{A}_{\mathrm{im}(\mathrm{a})}}\right\} \in[0,1]
$$

In module 3 (inference), the logical connectors used to establish the fuzzy relationship for rule base modeling were defined. The relationship between linguistic variables was characterized by the fuzzy system operator (MIN). In each rule a fuzzy relation $\mathrm{R}_{\mathrm{i}}$ was considered where the degree of relevance/pertinence for each pair $(a, b)$ is:

$$
\mu_{\mathrm{R}_{\mathrm{i}}}(\mathrm{a}, \mathrm{b})=\min \left\{\mu_{\mathrm{A}_{\mathrm{i}}}(\mathrm{a}), \mu_{\mathrm{B}_{\mathrm{i}}}(\mathrm{b})\right.
$$

The relationship between each rule is characterized by the operator (MAX), of the fuzzy R relationship that represents the

\begin{tabular}{|c|c|c|c|c|c|c|c|c|}
\hline \multicolumn{2}{|c|}{$\mathrm{N}\left(\mathrm{kg} h \mathrm{a}^{-1}\right)$} & \multicolumn{2}{|c|}{ TS (degree $d^{-1}$ ) } & \multicolumn{2}{|c|}{$\mathrm{PP}(\mathrm{mm})$} & \multicolumn{3}{|c|}{$P G\left(\mathrm{~kg} \mathrm{ha}^{-1}\right)$} \\
\hline$\overline{V_{L}}$ & $V_{a}$ & $\overline{V_{L}}$ & $V_{a}$ & $\bar{V}_{L}$ & $V_{0}$ & $V_{3}$ & $V_{3} / V_{6}$ & $\mathbf{V}_{3} / \mathbf{E}$ \\
\hline & & \multirow{3}{*}{ B } & & าea & $014+$ & 016) & & \\
\hline \multirow{4}{*}{ B } & \multirow{4}{*}{$0,30[$} & & \multirow{2}{*}{1575} & B & 893 & MB & MB & MB \\
\hline & & & & A & 893 & B & B & B \\
\hline & & & & B & 893 & MB & $\mathrm{MB}$ & $\mathrm{MB}$ \\
\hline & & A & $15 / 5$ & A & 893 & MB & MB & MB \\
\hline \multirow{4}{*}{ I } & \multirow{4}{*}{$30,90[$} & 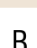 & 1575 & B & 893 & $M$ & $M$ & M \\
\hline & & B & $15 / 5$ & $A$ & 893 & M & M & M \\
\hline & & & & B & 893 & M & M & M \\
\hline & & A & $15 / 5$ & $A$ & 893 & M & M & M \\
\hline \multirow{4}{*}{ A } & \multirow{4}{*}[90,120]{} & $\mathrm{B}$ & 1575 & B & 893 & M & M & M \\
\hline & & B & $15 / 5$ & A & 893 & A & A & A \\
\hline & & $A$ & 1575 & B & 893 & M & M & M \\
\hline & & A & $15 / 5$ & A & 893 & A & A & A \\
\hline \multirow{2}{*}{ Real value } & Minimum & - & - & - & - & 1056 & 891 & 897 \\
\hline & Maximum & - & - & - & - & 4000 & 4076 & 4000 \\
\hline & & \multicolumn{7}{|c|}{ Corn/wheat system $(2014+2015+2016)$} \\
\hline \multirow{4}{*}{ B } & \multirow{4}{*}{$0,30[$} & \multirow{2}{*}{ B } & \multirow{2}{*}{1575} & $\mathrm{~B}$ & 893 & MB & MB & MB \\
\hline & & & & $A$ & 893 & B & B & B \\
\hline & & & & $\mathrm{B}$ & 893 & MB & MB & $\mathrm{MB}$ \\
\hline & & A & 1575 & $A$ & 893 & MB & MB & MB \\
\hline \multirow{4}{*}{ I } & \multirow{4}{*}{$30,90[$} & & & B & 893 & M & M & M \\
\hline & & B & $15 / 5$ & $A$ & 893 & M & M & M \\
\hline & & & & B & 893 & M & M & M \\
\hline & & A & $15 / 5$ & $A$ & 893 & M & M & M \\
\hline \multirow{4}{*}{ A } & \multirow{4}{*}[90,120]{} & & & B & 893 & M & M & M \\
\hline & & B & $15 / 5$ & A & 893 & A & A & A \\
\hline & & & & B & 893 & M & M & M \\
\hline & & A & $15 / 5$ & A & 893 & A & A & A \\
\hline \multirow{2}{*}{ Real value } & Minimum & - & - & - & - & 648 & 518 & 411 \\
\hline & Maximum & - & - & - & - & 3500 & 3600 & 3000 \\
\hline
\end{tabular}

Table 1. Fuzzy rule base for wheat grain yield simulation

N - Nitrogen; TS - Thermal sum; PP - Rainfall V - Linguistic variables; V - Quantitative variables; PG - Grain yield; MB - Very low; B - Low; M - Mean; A - high; I - Intermediate $\mathrm{V}_{3}$ - Full condition (100\%) of nitrogen dose in the third expanded leaf; $\mathrm{V}_{3} / \mathrm{V}_{6}$ - Fractionated condition $(70 \% / 30 \%)$ of nitrogen dose in the third and sixth expanded leaf; $\mathrm{V}_{3} / \mathrm{E}$ - Fractionated condition $(70 \% / 30 \%)$ of the nitrogen dose in the third expanded leaf and initiation of grain filling 
model determined by a rule base obtained by the MAX Union of each individual rule, so that for each pair $(a, b)$ is obtained:

$$
\mu_{\mathrm{R}}(\mathrm{a}, \mathrm{b})=\max _{1 \leq \mathrm{i} \leq \mathrm{n}}\left\{\mu_{\mathrm{A}_{\mathrm{i}}}(\mathrm{a})^{\wedge} \mu_{\mathrm{B}_{\mathrm{i}}}(\mathrm{b})\right\}
$$

where $\wedge$ represents the MIN operator.

By the Mamdani method the pertinence function of $B$ is given by:

$$
\mu_{\mathrm{B}}(\mathrm{b})=\max _{1 \leq \mathrm{i} \leq \mathrm{n}}\left\{\max _{\mathrm{a}}\left\{\mu_{\mathrm{A}}(\mathrm{a}) \wedge \mu_{\mathrm{Ai}}(\mathrm{a})\right\} \wedge \mu_{\mathrm{Bi}}(\mathrm{b})\right\}
$$

If the input is a classic unitary set, then $\mu_{\mathrm{A}}(\mathrm{a})=1$ and $\mu_{\mathrm{Ai}}(\mathrm{a})$ $\leq 1$. Therefore, the above expression results in:

$$
\left.\mu_{\mathrm{B}}(\mathrm{b})=\max _{1 \leq i \leq \mathrm{n}}\left\{\mu_{\mathrm{Ai}}(\mathrm{a})\right\}^{\wedge} \mu_{\mathrm{Bi}}(\mathrm{b})\right\}
$$

Therefore, the fuzzy set B represents the action for each input A. In Module 4 (defuzzification), the state of the fuzzy output variable provides the numerical value. One of the main methods of defuzification is the center of mass which for continuous variables is given by the expression:

$$
m(B)=\frac{\int b_{\mu B}(b) d b}{\int \mu_{B}(b) d b}
$$

and discrete variables by the expression:

$$
\mathrm{m}(\mathrm{B})=\frac{\sum_{\mathrm{b}} \mathrm{b}_{\mu \mathrm{B}}(\mathrm{b}) \mathrm{db}}{\sum_{\mathrm{b}} \mathrm{b}_{\mu \mathrm{B}}(\mathrm{b}) \mathrm{b}}
$$

The fuzzy controller is described as a function $f: R_{n} \rightarrow R_{m}$, since given an input value, there is a single corresponding output value.

To validate the rule base and simulated values of grain yield by fuzzy logic, the behavior and regression parameters obtained by the observed points and simulation, and the lower and upper limits of the confidence interval of the real values of the average of three agricultural harvests were considered at 0.05 level of probability of error. For the determination of regression models, confidence interval and mean comparison test of Scott \& Knott, the computational program Genes was utilized.

\section{RESUlts AND Discussion}

In the agricultural year 2016 (Figure 1A), the maximum temperature observed at the time and after application of $\mathrm{N}$-fertilizer was not high $\left( \pm 15^{\circ} \mathrm{C}\right)$ and had favorable soil moisture conditions due to the rainfall that occurred in the days prior to fertilization. In addition, adequate rainfall
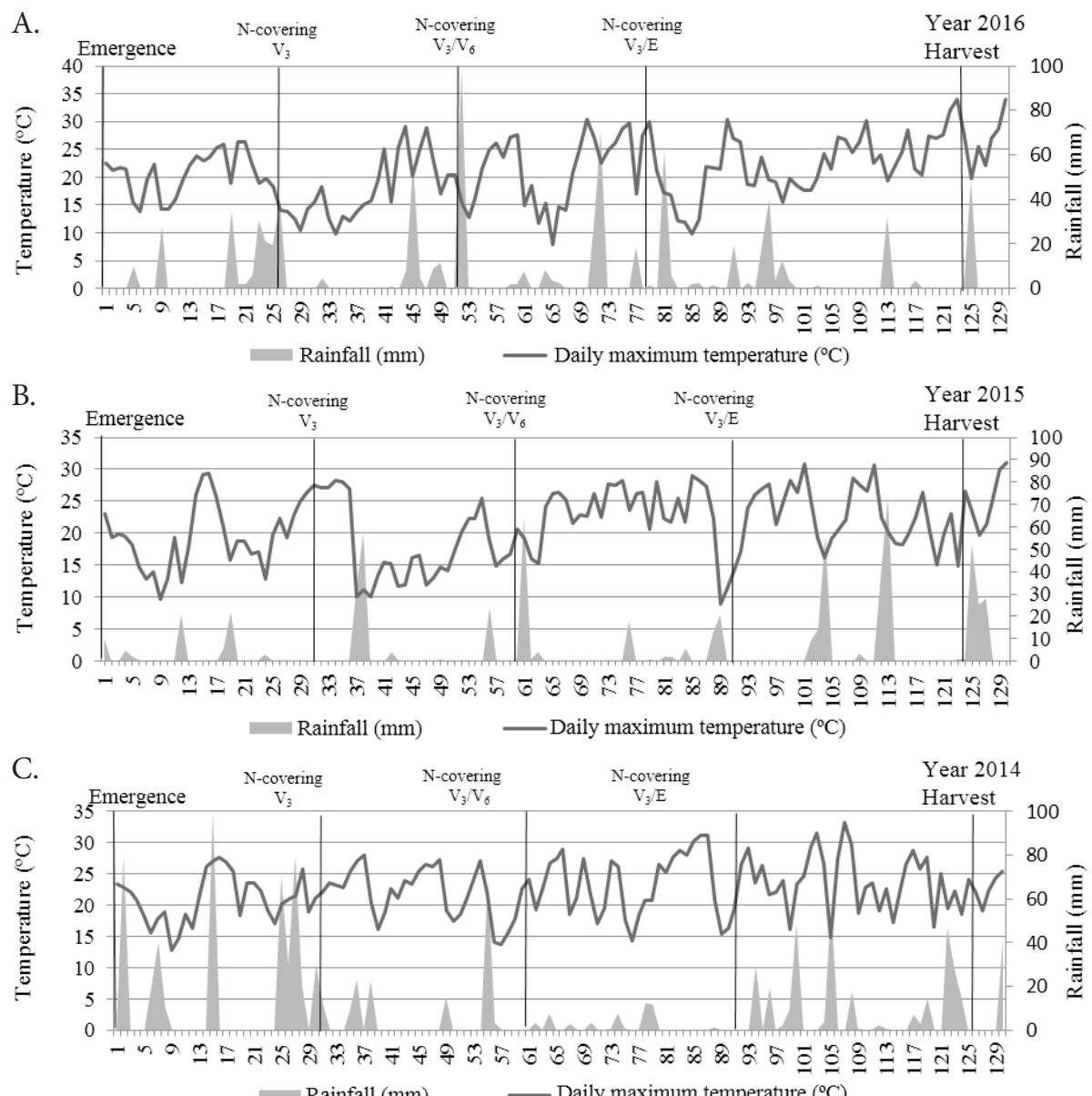

Rainfall $(\mathrm{mm}) \quad$ Daily maximum temperature $\left({ }^{\circ} \mathrm{C}\right)$

$\mathrm{V}_{3}$ - Full condition (100\%) of the nitrogen dose in the third expanded leaf. $\mathrm{V}_{3} / \mathrm{V}_{6}$ - Fractionated condition (70\%/30\%) of the nitrogen dose in the third and sixth expanded leaf; $\mathrm{V}_{3} / \mathrm{E}$ - Fractionated condition $(70 \% / 30 \%)$ of the nitrogen dose in the third expanded leaf and initiation of grain filling

Figure 1. Rainfall and maximum temperature in the wheat growing cycle and the moment of nitrogen supply. Emergence: 2016 $(17 / 06)(\mathrm{A}) ; 2015(27 / 06)(B)$ and $2014(25 / 06)(\mathrm{C})$ 
distribution was observed throughout the cycle. These conditions were decisive in the higher efficiency of nitrogen use to the expression of high productivity, characterizing the year 2016 as favorable (AF) to the cultivation of wheat (Table 2). In 2015 (Figure 1B), the maximum temperatures at the beginning of wheat development were high $\left(\approx 27^{\circ} \mathrm{C}\right)$. This condition favors faster elongation with reduced yield of new tillers, a component directly linked to grain yield. The high temperatures and no rainfall caused reduced soil moisture at the time of nitrogen fertilization, conditions that favor nutrient losses by volatilization. The meteorological information along with the productivity obtained, characterized 2015, as a reasonable year (AR) for the cultivation (Table 2; Figure 1B). In the year 2014 (Figure 1C), although at the time of nitrogen supply, the maximum temperature was intermediate $\left(\approx 23^{\circ} \mathrm{C}\right)$, the nutrient application was followed by a significant volume of rainfall $(\approx 30 \mathrm{~mm})$, favoring leaching. In addition, the large rainfall period and volume affected radiation quality during the grain filling phase and grain harvest. These facts justify the low grain yield obtained in 2014 (Table 2; Figure 1C), characterized as an unfavorable year (AD) for wheat cultivation.

In wheat crop, although the management of agricultural practices is decisive for higher yields, the rainfall and air temperature are meteorological variables that determine the success of agricultural harvests (Arenhardt et al., 2015; Salton et al., 2016). Rain is directly linked to nutrient utilization efficiency such as nitrogen, because the correct absorption is a function of adequate soil moisture. High temperatures promote reduced productivity and reduced biomass accumulation due to the lower net photosynthesis obtained due to increased respiration rate, reducing the efficiency of nitrogen utilization (Arenhardt et al., 2015; Mantai et al., 2016). The supply of nitrogen followed by excessive rainfall promotes losses by leaching, and when supplied with reduced soil moisture and high air temperature, cause volatilization losses, therefore reducing productivity, generating environmental contamination and collaborating on events related to global warming (Mandal et al., 2016; Arenhardt et al., 2017).

Figure 2 shows the behavior and parameters of the equation for biological interpretation of nitrogen utilization to grain yield, considering in each model the starting point of performance, given by the linear coefficient (a) and the slope of the line by the angular coefficient $\left(b_{x}\right)$ in the comparison between the real data and those simulated by fuzzification. It is noteworthy that the parameter $b_{x}$ of the linear equation provides the agronomic efficiency, indicating the relationship between the productivity obtained per unit of nitrogen supplied. In this perspective, the behavior and values of the linear coefficients of observed and simulated productivity were similar. In addition, the tendency and slope values in the estimation of the behavior and agronomic efficiency were also close to the real and simulated values. It stands out as an example, the supply of nitrogen in full dose in the phenological stage $\mathrm{V}_{3}$ in the soybean/wheat system, showing that for every $1 \mathrm{~kg} \mathrm{ha}^{-1}$ of nitrogen provided there is an increment of $11 \mathrm{~kg} \mathrm{ha}^{-1}$ of grain yield in the real condition of cultivation, with return of $10 \mathrm{~kg} \mathrm{ha}^{-1}$ productivity considering the simulation results (Figure 2).

In Tables 3 and 4 of the soybean/wheat and corn/ wheat system, respectively, the increase of nitrogen doses in the real cultivation conditions showed increase of grain yield, independent of the supply (full or fractionated) and succession system (soybean/wheat; corn/wheat). In the soybean/wheat system, the application of nitrogen in full and fractionated doses showed no change in wheat yield (Table 3 ). On the other hand, in the corn/wheat system, the more restrictive $\mathrm{N}$-residual condition showed higher fertilization dependence in the early stages of development in $\mathrm{V}_{3}$ and $\mathrm{V}_{3} / \mathrm{V}_{6}$ fractionated conditions, with reduced grain yield fractionation (Table 4).

Tables 3 and 4 also show a trend of higher wheat yield due to the increase of $\mathrm{N}$-fertilizer obtained by the simulation

Table 2. Temperature and precipitation in the months of cultivation and average productivity

\begin{tabular}{|c|c|c|c|c|c|c|c|c|}
\hline \multirow{2}{*}{ Year } & \multirow{2}{*}{ Month } & \multicolumn{3}{|c|}{ Temperature $\left({ }^{\circ} \mathrm{C}\right)$} & \multicolumn{2}{|c|}{ Precipitation (mm) } & \multirow{2}{*}{$\begin{array}{c}P_{\mathrm{PG}} \\
\left(\mathrm{kg} \mathrm{ha}^{-1}\right)\end{array}$} & \multirow{2}{*}{ Class } \\
\hline & & Minimum & Maximum & Mean & Mean of 26 years* & Occurrence & & \\
\hline \multirow{7}{*}{2014} & May & 10.8 & 23.6 & 17.2 & 149.7 & 412 & \multirow{7}{*}{$1441 \mathrm{c}$} & \multirow{7}{*}{$A D$} \\
\hline & June & 8.6 & 19 & 13.8 & 162.5 & 412 & & \\
\hline & July & 9.7 & 21.82 & 15.76 & 135.1 & 144 & & \\
\hline & August & 8.8 & 23.66 & 16.23 & 138.2 & 77.8 & & \\
\hline & September & 13.33 & 23.58 & 18.46 & 167.4 & 274.8 & & \\
\hline & October & 16.02 & 27.49 & 21.76 & 156.5 & 230.8 & & \\
\hline & Total & - & - & - & 909.4 & 1551.4 & & \\
\hline \multirow{7}{*}{2015} & May & 11.1 & 24.5 & 17.8 & 149.7 & 20.3 & \multirow{7}{*}{$2441 b$} & \multirow{7}{*}{ AR } \\
\hline & June & 9.3 & 19.7 & 14.5 & 162.5 & 59.4 & & \\
\hline & July & 7.4 & 17.5 & 12.4 & 135.1 & 176.6 & & \\
\hline & August & 12.9 & 23.4 & 18.1 & 138.2 & 61.4 & & \\
\hline & September & 12 & 23 & 17.5 & 167.4 & 194.6 & & \\
\hline & October & 15 & 25.5 & 20.2 & 156.5 & 286.6 & & \\
\hline & Total & - & - & - & 909.4 & 798.9 & & \\
\hline \multirow{7}{*}{2016} & May & 10.5 & 22.7 & 16.6 & 149.7 & 100.5 & \multirow{7}{*}{$3357 \mathrm{a}$} & \multirow{7}{*}{$\mathrm{AF}$} \\
\hline & June & 7.9 & 18.4 & 13.15 & 162.5 & 191 & & \\
\hline & July & 8.3 & 19.2 & 13.75 & 135.1 & 200.8 & & \\
\hline & August & 9.3 & 20.4 & 14.85 & 138.2 & 223.8 & & \\
\hline & September & 9.5 & 23.7 & 16.6 & 167.4 & 46.5 & & \\
\hline & October & 12.2 & 25.1 & 18.65 & 156.5 & 211.3 & & \\
\hline & Total & - & - & - & 909.4 & 973.9 & & \\
\hline
\end{tabular}

${ }^{*}$ Mean rainfall obtained from May to October 1990 to 2016; Means followed by the same letter in the column do not differ from each other at $\mathrm{p} \leq 0.05$ by the Scott \& Knott test; AR - Reasonable year; AF - Favorable year; AD - Unfavorable year; $\mathrm{PG}_{\mathrm{X}}$ - Mean grain yield 


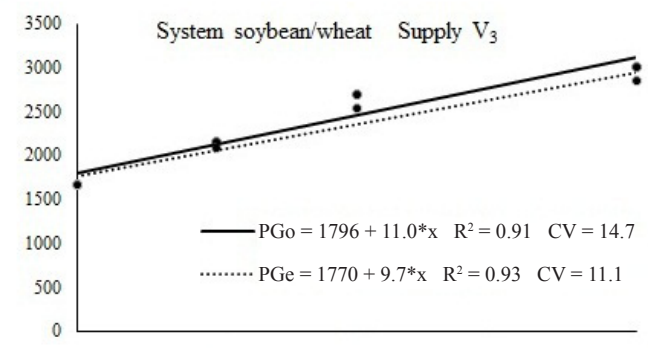

C.
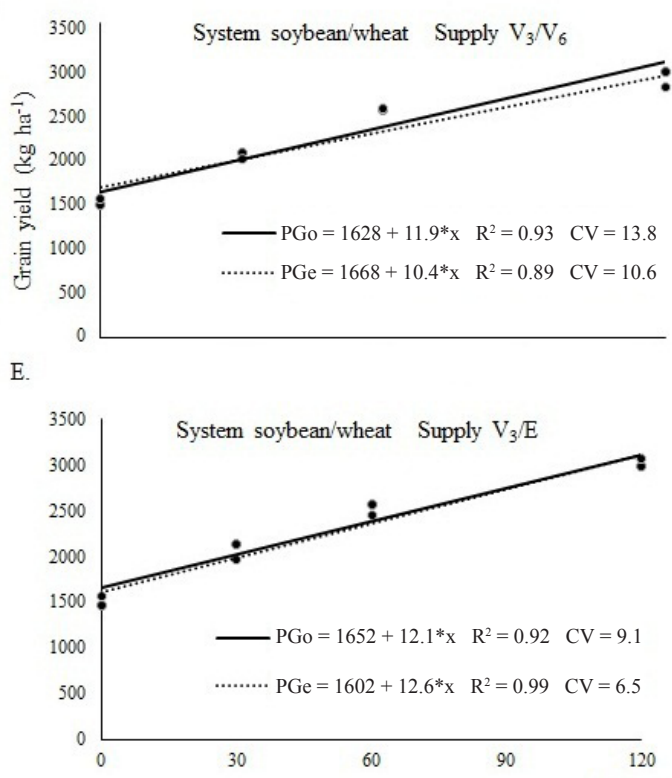

B.

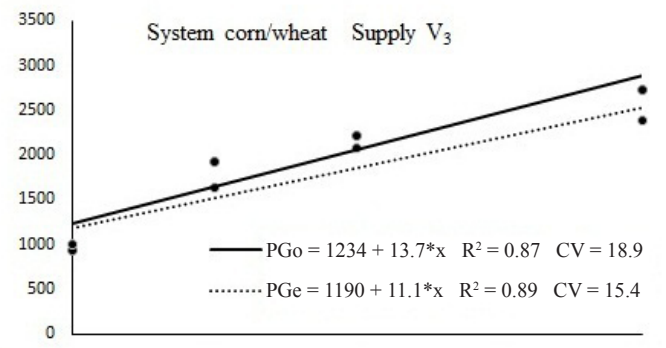

D.

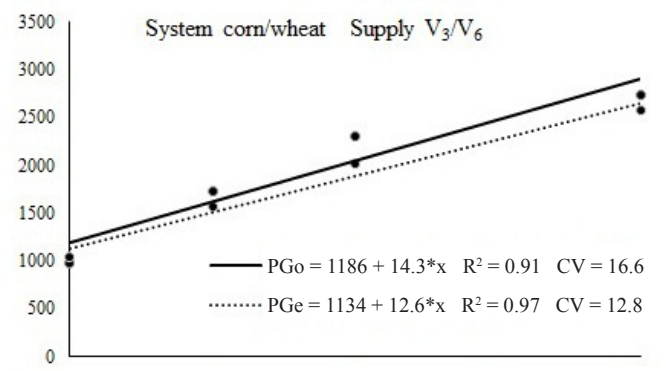

F.

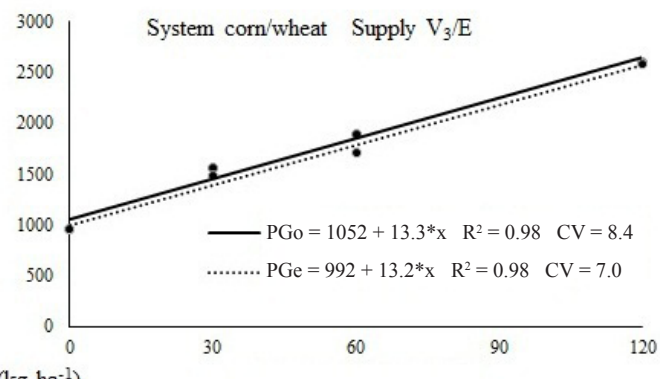

* Significant of $\mathrm{p} \leq 0.05$ by $\mathrm{F}$ test

$\mathrm{V}_{3}$-Full condition $(100 \%)$ of the nitrogen dose in the third expanded leaf; $\mathrm{V}_{3} / \mathrm{V}_{6}$-Fractional condition $(70 \% / 30 \%)$ of the nitrogen dose in the third and sixth expanded leaf; $\mathrm{V}_{3} / \mathrm{E}$ Fractionated condition $(70 \% / 30 \%)$ of nitrogen dose in the third expanded leaf and initiation of grain filling; PGo - Observed grain yield (kg ha $\left.{ }^{-1}\right)$; PGe - Estimated grain yield (kg $\left.\mathrm{ha}^{-1}\right) ;{ }^{*}$ Significant at $\mathrm{p} \leq 0.05$ by the F test; $\mathrm{R}^{2}$ - Coefficient of determination; CV - Coefficient of variation

Figure 2. Condition of nitrogen use: $\mathrm{A}$ - Supply in $\mathrm{V}_{3}$ (soybean/wheat); B - Supply in $\mathrm{V}_{3}$ (corn/wheat); $\mathrm{C}-\mathrm{Supply}$ in $\mathrm{V}_{3} / \mathrm{V}_{6}$ (soybean/wheat); D - Supply in $\mathrm{V}_{3} / \mathrm{V}_{6}$ (corn/wheat); $\mathrm{E}$ - Supply in $\mathrm{V}_{3} / \mathrm{E}$ (soybean/wheat); F - Supply in $\mathrm{V}_{3} / \mathrm{E}$ (corn/wheat)

Table 3. Fuzzy logic in the simulation of wheat yield by nitrogen doses, thermal sum and temperature under nitrogen use conditions in the soybean/wheat system

\begin{tabular}{|c|c|c|c|c|c|c|}
\hline \multirow{2}{*}{$\begin{array}{l}\text { Phenological } \\
\text { stage }\end{array}$} & \multirow{2}{*}{$\begin{array}{c}N \\
\left(k^{\prime} h a^{-1}\right)\end{array}$} & \multicolumn{3}{|c|}{ PGo $\left(k_{g} h^{-1}\right)$} & \multirow{2}{*}{$\begin{array}{l}P G_{e}\left(k_{g} h^{-1}\right) \\
\text { Fuzzy model }\end{array}$} & \multirow{2}{*}{$\begin{array}{c}\text { Absolute } \\
\text { error }\end{array}$} \\
\hline & & $\overline{L_{i}}$ & $\bar{x}$ & $\overline{L_{s}}$ & & \\
\hline \multirow{5}{*}{$V_{3}$} & & \multicolumn{5}{|c|}{$(2014+2015+2016)$} \\
\hline & 0 & 1446 & 1659 & 1880 & 1670 & 11 \\
\hline & 30 & 1456 & 2154 & 2842 & 2080 & 74 \\
\hline & 60 & 1897 & 2694 & 3598 & 2530 & 164 \\
\hline & 120 & 1928 & 2997 & 4624 & 2850 & 147 \\
\hline \multicolumn{2}{|l|}{ Mean $V_{3}$} & 1682 & $2376 \mathrm{Aa}$ & 3236 & $2283 \mathrm{Aa}$ & 93 \\
\hline \multirow{4}{*}{$V_{3} / V_{6}$} & 0 & 1291 & 1479 & 1697 & 1540 & 61 \\
\hline & 30 & 1734 & 2058 & 2698 & 1980 & 78 \\
\hline & 60 & 1775 & 2540 & 3422 & 2550 & 10 \\
\hline & 120 & 1816 & 2950 & 4535 & 2790 & 160 \\
\hline \multicolumn{2}{|c|}{ Mean $V_{3} V_{6}$} & 1654 & $2332 \mathrm{Aa}$ & 3088 & $2215 \mathrm{Aa}$ & 117 \\
\hline \multirow{4}{*}{$V_{3} / E$} & 0 & 1297 & 1469 & 1779 & 1570 & 101 \\
\hline & 30 & 1421 & 2138 & 2637 & 1960 & 178 \\
\hline & 60 & 1476 & 2562 & 3373 & 2450 & 112 \\
\hline & 120 & 1986 & 2984 & 4273 & 3070 & 86 \\
\hline Mean $V_{3} / E$ & & 1545 & $2288 \mathrm{Aa}$ & 3016 & $2263 \mathrm{Aa}$ & 25 \\
\hline
\end{tabular}

$\mathrm{V}_{3}$ - Full (100\%) nitrogen dose condition in the expanded third leaf; $\mathrm{V}_{3} / \mathrm{V}_{6}$ - Fractional condition $(70 \% / 30 \%)$ of nitrogen dose in the third and sixth expanded leaf; $\mathrm{V}_{3} / \mathrm{E}$

- Fractional condition $(70 \% / 30 \%)$ of nitrogen dose in the third expanded leaf and initiation of grain filling; $\mathrm{N}$-nitrogen; $\mathrm{L}_{\mathrm{i}}$ and $\mathrm{L}_{\mathrm{s}}$-Lower and upper limit of the confidence interval to $\mathrm{p} \leq 0.05$ by the Scott \& Knott test; $\mathrm{X}$-mean; $\mathrm{PG}_{\mathrm{O}}$ - observed grain yield; PG -Estimated grain yield. Means followed by the same uppercase letter in the row and lowercase in the column do not differ statistically from each other, at $\mathrm{p} \leq 0.05$ level by the Scott \& Knott test
Table 4. Fuzzy logic in the simulation of wheat yield by nitrogen doses, thermal sum and temperature in the conditions of nitrogen use in the corn/wheat system

\begin{tabular}{|c|c|c|c|c|c|c|}
\hline \multirow{2}{*}{$\begin{array}{c}\text { Phenological } \\
\text { stage }\end{array}$} & \multirow{2}{*}{$\begin{array}{c}\mathrm{N} \\
\left(\mathrm{kg} \mathrm{ha}^{-1}\right)\end{array}$} & \multicolumn{3}{|c|}{$P G_{0}\left(k g h a^{-1}\right)$} & \multirow{2}{*}{$\begin{array}{l}\mathrm{PG}_{\mathrm{s}}\left(\mathrm{kg} \mathrm{ha}^{-1}\right) \\
\text { Fuzzy model }\end{array}$} & \multirow{2}{*}{$\begin{array}{c}\text { Absolute } \\
\text { error }\end{array}$} \\
\hline & & $\overline{\mathbf{L}_{\mathrm{i}}}$ & $\bar{X}$ & $L_{s}$ & & \\
\hline \multirow{5}{*}{$V_{3}$} & & \multicolumn{5}{|c|}{$(2014+2015+2016)$} \\
\hline & 0 & 748 & 943 & 1111 & 997 & 54 \\
\hline & 30 & 1393 & 1924 & 2582 & 1640 & 284 \\
\hline & 60 & 1550 & 2222 & 2841 & 2070 & 152 \\
\hline & 120 & 1945 & 2728 & 3589 & 2390 & 338 \\
\hline Mean $V_{3}$ & & 1459 & $1954 \mathrm{Aa}$ & 2531 & $1838 \mathrm{Aa}$ & 116 \\
\hline \multirow{4}{*}{$V_{3} / V_{6}$} & 0 & 718 & 971 & 1155 & 1040 & 69 \\
\hline & 30 & 1351 & 1728 & 2021 & 1560 & 168 \\
\hline & 60 & 1799 & 2304 & 2812 & 2010 & 294 \\
\hline & 120 & 1714 & 2739 & 3681 & 2580 & 159 \\
\hline Mean $V_{3} / V_{6}$ & & 1396 & $1926 \mathrm{Aa}$ & 2417 & $1823 \mathrm{Aa}$ & 103 \\
\hline \multirow{4}{*}{$V_{3} / E$} & 0 & 811 & 954 & 1031 & 954 & 0 \\
\hline & 30 & 1256 & 1558 & 1912 & 1490 & 68 \\
\hline & 60 & 1313 & 1789 & 2272 & 1710 & 79 \\
\hline & 120 & 1734 & 2479 & 3372 & 2590 & 11 \\
\hline Mean $V_{3} / E$ & & 1279 & $1695 \mathrm{Ab}$ & 2147 & $1524 \mathrm{Ab}$ & 171 \\
\hline
\end{tabular}

$\mathrm{V}_{3}$-Full condition (100\%) of the nitrogen dose in the third expanded leaf; $\mathrm{V}_{3} / \mathrm{V}_{6}$-Fractional condition $(70 \% / 30 \%)$ of the nitrogen dose in the third and sixth expanded leaf; $\mathrm{V}_{3} / \mathrm{E}-$ Fractional condition $(70 \% / 30 \%)$ of the nitrogen dose in the third expanded leaf and the initiation of grain filling; $\mathrm{N}$-nitrogen; $\mathrm{L}_{\mathrm{i}}$ and $\mathrm{L}_{\mathrm{s}}$ - Lower and upper confidence interval limit at $\mathrm{p} \leq 0.05$ by the Scott \& Knott test; $\mathrm{X}-\mathrm{Mean} ; \mathrm{PG}_{\mathrm{O}}$ - Observed grain yield; $\mathrm{PG}_{\mathrm{e}}$ - Estimated grain yield. Means followed by the same uppercase letter in the row and lowercase in the column do not differ statistically from each other, at $\mathrm{p} \leq 0.05$ level by the Scott \& Knott test 
result. The conditions mentioned for the absence of differences in the conditions of fertilization in the soybean/wheat system (Table 3 ) and reduction of productivity in the fractionation in $\mathrm{V}_{3} / \mathrm{V}_{6}$ were also recognized by the fuzzification process (Tables 3 and 4). Fuzzy rule-based simulation identified simulated productivity values in succession systems very close to the real results obtained by experimentation, all within the confidence interval of the average in each treatment. A surprising result that shows reduced absolute error between the real and simulated value of grain yield.

The functions of pertinence and linguistic values for simulation in this research were adequate for the fuzzification process, indicating the ability to recognize biological processes by set theory via fuzzy logic. Thus, indicating the obtaining of reliable data by integrating information between the plant, nitrogen management and weather conditions in the simulation. In this perspective, new opportunities open up given these characteristics in the development of more efficient models in areas where it is necessary to deal with uncertainty and subjectivity, a common condition in agriculture where the predictability of crops is sought.

Silva et al. (2014) used fuzzy logic to estimate wheat grain yield, showing that the model allowed an adequate estimation of wheat grain yield by nitrogen use, not taking into account the non-linear conditions of meteorological elements. Francisco et al. (2007), developed a fuzzy model to estimate the soybean sowing area from vegetation image indexes, showing to be highly correlated with the official estimates. Campos et al. (2013) developed a fuzzy model to predict the occupancy rate of stalls in free-stall dairy cattle installations, assisting in optimizing project sizing. Through fuzzy logic, Ponciano et al. (2011) exemplified successful situations in predicting the variables that affect thermal comfort for broilers, supporting decision making in controlling the climate of poultry houses. Cavalcanti et al. (2013) used fuzzy logic to evaluate the sensory acceptance of bread enriched with seeds of 'faveleira' (Cnidoscolus quercifolius), plant originating from the Brazilian Northeast with high quality omega- 6 fatty acids. Khatchatourian \& Treter (2010) developed a methodology based on fuzzy logic for evaluation and classification of economic and financial performance of agricultural cooperatives. Maranduba et al. (2016) used fuzzy logic to evaluate the viability of the life cycle of biodiesel produced in Brazil, considering two mixing scenarios: B7 (7\% Biodiesel and 93\% fossil diesel) and B10 (10\% biodiesel and $90 \%$ of fossil diesel). Cardoso et al. (2018), through Fuzzy logic, was able to characterize and successfully map the uncertainties of both rainfall and erosivity to the state of Bahia, Brazil.

\section{Conclusions}

1. The pertinence functions and linguistic values established for the input and output variables are adequate for the use of fuzzy logic.

2. Fuzzy logic efficiently simulates wheat grain yield under conditions of nitrogen use with air temperature and rainfall in the cultivation systems.

\section{ACKNOWLedgement}

To CNPq, CAPES, FAPERGS and UNIJUÍ, for the funding provided towards the development of this study and the scholarships for scientific and technological initiation, technical support, post-graduate research and productivity.

\section{Literature Cited}

Acosta, J. A. de A.; Amado, T. J. C.; Silva, L. S. da; Santi, A.; Weber, M. A. Decomposição da fitomassa de plantas de cobertura e liberação de nitrogênio em função da quantidade de resíduos aportada ao solo sob sistema plantio direto. Ciência Rural, v.44, p.801-809, 2014. https://doi.org/10.1590/S0103-84782014005000002

Arenhardt, E. G.; Silva, J. A. G.da; Arenhardt, L. G.; Silva, D. R. da; Gzergorczick, M. E.; Ceolin, G. P.; Stülp, C.; Figueiredo, R. G.; Oliveira, A. C. de.Technical and agronomic efficiency of oat cultivars as a function of nitrogen availability.Científica, v.45, p.257-270, 2017. https://doi.org/10.15361/19845529.2017v45n3p257-270

Arenhardt, E. G.; Silva, J. A. G. da; Gewehr, E.; Oliveira, A. C. de; Binelo, M. O.; Valdiero, A. C.; Gzergorczick, M. E.; Lima,A. R. C. de.The nitrogen supply in wheat cultivation dependent on weather conditions and succession system in southern Brazil. African Journal of Agricultural Research, v.10, p.4322-4330, 2015. https://doi.org/10.5897/AJAR2015.10038

Barros, L. C.; Bassanezi, R. C. Tópicos de lógica fuzzy e biomatemática. 2.ed. Campinas: UNICAMP/IMECC, 2010. 393p.

Camponogara, A. da S.; Oliveira, G. A.; Georgin, J.; Rosa, A. L. D. da.Avaliação dos componentes de rendimento do trigo quando submetido a diferentes fontes de nitrogênio. Revista Eletrônica em Gestão, Educação e Tecnologia Ambiental, v.2, p.524-532, 2016.

Campos, A. T.; Castro, J. de O.; Schiassi, L.; Yanagi Junior, T.; Pires, M. de F. Á.; Mattioli, C. C. Predição da taxa de ocupação de baias em instalações tipo free-stall para bovinos de leite por meio dos conjuntos fuzzy. Engenharia Agrícola,v.33, p.1079-1089, 2013. https://doi.org/10.1590/S0100-69162013000600001

Cardoso, Y. S.; Lopes, M. R.; Silva, S. de A.; Alves, D. I.; Lima, J. S. de S. Distribuição e incerteza da precipitação pluviométrica e do potencial erosivo das chuvas para o Estado da Bahia, Brasil. Revista Engenharia na Agricultura, v.26, p.149-159, 2018. https:// doi.org/10.13083/reveng.v26i2.835

Cavalcanti,M. T.; Silva, F. L. H. da; Cavalcanti, J. H. F.; Florentino, E. R.; Florêncio, I. M.; Moreira, R. T. Aplicação da lógica fuzzy na análise sensorial de pão de forma enriquecido. Revista Brasileira de Engenharia Agrícola e Ambiental, v.17, p.208-215, 2013. https://doi.org/10.1590/S1415-43662013000200012

Cecconello, M. S.; Silva, J. de D. M. de; Bassanezi, R. C. Sistemas dinâmicos fuzzy: Modelagens alternativas para sistemas biológicos. 50.ed. São Carlos: Sociedade Brasileira de Matemática Aplicada, 2010. 120p.

Costa, J. S. P.; Mantai, R. D.; Silva, J. A. G. da; Scremin, O. B.; Arenhardt, E. G.; Lima, A. R. C. de. Single and split nitrogen dose in wheat yield indicators. Revista Brasileira de Engenharia Agrícola e Ambiental, v.22, p.16-21, 2018. https://doi. org/10.1590/1807-1929/agriambi.v22n1p16-21 
Crusiol, L. G. T.; Pereira Neto, O. C.; Nanni, M. R.; Gualberto, A. A. S.; Furlanetto, R. H.; Silva Junior,C. A. da. Mapeamento de áreas agrícolas na safra de verão a partir de imagens Landsat frente aos dados oficiais. Revista Agro@mbiente On-line, v.10, p.287-298, 2016. https://doi.org/10.18227/1982-8470ragro.v10i4.3098

Francisco, J.; Antunes, G.; Zullo Júnior, J. Aplicação de lógica fuzzy para estimativa de área plantada da cultura de soja utilizando imagens AVHRR-NOAA. Master, v.1, p.35-42, 2007.

Goergen,P. C. H.; Krüger, C. A. M. B.; Bianchi, V.; Silva, I. W. da; Gehrke, I. T. S.; Corrêa, J. B.; Silva, J. A. G. da.Effects of Schinus terebinthifolius extracts on the control of Sitophilus species in stored wheat grains. African Journal of Agricultural Research, v.12, p.3556-3561, 2017. https://doi.org/10.5897/AJAR2017.12621

Gomes, A. C. dos S.; Robaina, A. D.; Peiter, M. X.; Soares, F. C.; Parizi, A. R. C. Modelo para estimativa da produtividade para a cultura da soja. Ciência Rural, v.44, p.43-49, 2014. https://doi.org/10.1590/ S0103-84782013005000145

Khatchatourian, O.; Treter, J. Aplicação da lógica fuzzy para avaliação econômico-financeira de cooperativas de produção. Journal of Information Systems and Technology Management, v.7, p.141161, 2010. https://doi.org/10.4301/S1807-17752010000100006

Mandal, S.; Thangarajan, R.; Bolan, N. S.; Sarkar, B.; Khan, N.; Sik Ok, Y.; Naidu, R. Biochar-induced concomitant decrease in ammonia volatilization and increase in nitrogen use efficiency by wheat. Chemosphere, v.142, p.120-127, 2016. https://doi.org/10.1016/j. chemosphere.2015.04.086

Mantai, R. D.; Silva, J. A. G. da; Arenhardt, E. G.; Scremin, O. B.; Mamann, Â. T. W.; Frantz, R. Z.; Valdiero, A. C.; Pretto, R.; Krysczun, D. K. Simulation of oat grain (Avena sativa) using its panicle components and nitrogen fertilizer. African Journal of Agricultural Research, v.11, p.3975-3983, 2016. https://doi. org/10.5897/AJAR2016.10943

Mantai, R. D.; Silva, J. A. G.da; Marolli, A.; Mamann, Â. T. W. de; Sawicki, S.; Krüger, C. A. M. B. Simulation of oat development cycle by photoperiod and temperature. Revista Brasileira de Engenharia Agrícola e Ambiental,v.21, p.3-8, 2017. https://doi. org/10.1590/1807-1929/agriambi.v21n1p3-8

Maranduba, H. L.; Ribeiro, E. L. F.; Vieira, J.; Cruz, R. S. da; Oliveira, F. B. S.; Almeida Neto, J. A. de. Uso da Lógica Fuzzy na avaliação da viabilidade do ciclo de vida do biodiesel. Revista LatinoAmericana em Avaliação do Ciclo de Vida, v.1, p.22-33, 2016. https://doi.org/10.18225/lalca.v1i1.3070
Marolli. A.; Silva, J. A. G. da; Sawicki, S.; Binelo, M. O.; Scremin, A. H.; Reginatto, D. C.; Dornelles, E. F.; Lambrecht, D. M. A simulação da biomassa de aveia por elementos climáticos, nitrogênio e regulador de crescimento. Arquivo Brasileiro de Medicina Veterinária e Zootecnia, v.70, p.535-544, 2018. https:// doi.org/10.1590/1678-4162-9504

Marolli, A.; Silva, J. A. G. da; Scremin, O. B.; Mantai, R. D.; Trautmann, A. P. B.; Mamann, Â. T. W.de; Carbonera, R.; Kraisig, A. R.; Krüger, C. A. M. B.; Arenhardt, E. G. A proposal of oat productivity simulation by meteorological elements, growth regulator and nitrogen. American Journal of Plant Sciences, v.8, p.2101-2118, 2017. https://doi.org/10.4236/ajps.2017.89141

Pedro Júnior, M.J.; Camargo, M.B. P. de; Moraes, A.V. de C.; Felício, J.C.; Castro, J.L. Temperatura-base, graus-dia e duração do ciclo para cultivares de triticale. Bragantia, v.63, p.447-453, 2004. https://doi.org/10.1590/S0006-87052004000300015

Ponciano, P.F.; Lopes, M.A.; Yanagi Junior, T.; Ferraz, G.A.S. Análise do ambiente para frangos por meio da lógica fuzzy: Uma revisão. Arquivos de Zootecnia, v.60, p.1-13, 2011. https://doi. org/10.21071/az.v60i232.4913

Rosa, H. T.; Walter, L. C.; Streck, N. A.; Carli, C. de; Ribas, G. G.; Marchesan, E. Simulação do crescimento e produtividade de arroz no Rio Grande do Sul pelo modelo SimulArroz. Revista Brasileira de Engenharia Agrícola e Ambiental, v.19, p.11591165, 2015. https://doi.org/10.1590/1807-1929/agriambi. v19n12p1159-1165

Salton, F. G.; Morais,H.; Caramori, P. H.; Borrozzino, E. Climatologia dos episódios de precipitação em três localidades no estado do Paraná. Revista Brasileira de Meteorologia, v.31, p.626-638, 2016. https://doi.org/10.1590/0102-7786312314b20150108

Santos, S. M. C.; Antonangelo, J. A.; Deus, A. C. F.; Fernandes, D. M. Perdas de amônia por volatilização em resposta a adubação nitrogenada do feijoeiro. Revista de Agricultura Neotropical, v.3, p.16-20, 2016. https://doi.org/10.32404/rean.v3i1.545

Silva, A.A.V. da; Silva, I.A.F.; Teixeira Filho, M.C.M.; Buzetti, S.; Teixeira, M.C.M. Estimativa da produtividade de trigo em função da adubação nitrogenada utilizando modelagem neuro-fuzzy. Revista Brasileira de Engenharia Agrícola e Ambiental, v.18, p.180187, 2014. https://doi.org/10.1590/S1415-43662014000200008

Tedesco, M. J.;Gianello, C.; Bissani, C. A.; Bohnen, H.; Volkweiss, S. J. Análise de solo, plantas e outros materiais. 2.ed. Porto Alegre: Universidade Federal do Rio Grande do Sul, 1995. 174p. 